\title{
Community-based Ecotourism Management in Cikakak Village, Wangon District, Banyumas Regency
}

\author{
Feri Ardiansyah ${ }^{2}$, Rina Kurniati ${ }^{2}$, and Amirudin Amirudin ${ }^{3}$ \\ ${ }^{1}$ Master Program in Environmental Science, School of Postgraduate Studies, Universitas Diponegoro, \\ Semarang Indonesia \\ ${ }^{2}$ Department of Urban and Regional Planning, Faculty of Engineering, Universitas Diponegoro, \\ Semarang Indonesia \\ ${ }^{3}$ Department of Social Antropology, Faculty of Humanity, Universitas Diponegoro, Semarang \\ Indonesia
}

\begin{abstract}
Indonesia is the country blessed with natural beauty. This is an opportunity to develop many ecotourism destinations. One of the potential areas to develop ecotourism is Cikakak Village, Banyumas Regency. This research aims to explore the potential of ecotourism in Cikakak Village and identify the pattern of ecotourism management. Data collection methods in this study were conducted by questionnaires, observations and interviews. Ecotourism Cikakak Village has tourist attractions in the form of Curug Antap and Saka Tunggal Mosque. Curug Antap is managed by tourism conscious groups (pokdarwis), while the management of Saka Tunggal Mosque is carried out by the Aboge community which makes Saka Tunggal Mosque the center of traditional and religious rituals. The results of measuring the participation rate of the community using questionnaires showed a value of $69,57 \%$ (quite high). The highest indicator of community participation in the organization and control of the community to resources with a value of $77 \%$. SWOT analysis of economic, ecological and ecotourism management aspects in Cikakak Village shows that ecotourism conditions are in quadrant I which is the most favorable position. Cikakak Village Ecotourism Manager can implement aggressive strategy by using its power to take advantage of existing opportunities.
\end{abstract}

\section{Introduction}

Indonesia is one of the countries blessed with natural beauty and mega biodiversity. Data from the Ministry of Energy and Mineral Resources shows that Indonesia has the most active mountains globally, which is 127 mountains. As an island nation, Indonesia also has the second-longest coastline in the world, with a length of about 95,181 km [1]. Indonesia also has a large forest area of 107.44 million $\mathrm{Ha}$ [2]. The wealth is the potential to develop various ecotourism in Indonesia. The development of ecotourism is expected to bring a multiplier effect for the regional economy and improve the community's welfare. Tourism is a sector

${ }^{*}$ Corresponding author: f3r1ardian@yahoo.com 
capable of accounting for an average of $4.4 \%$ of GDP, $6.9 \%$ of employment, and $21.5 \%$ of service exports [3]. According to the World Tourism Organization (WTO), starting in the 1990 s, people tended to travel back to nature [4]. Therefore, ecotourism is one of the suitable forms of tourism.

The International Ecotourism Society (TIES) defines ecotourism as a responsible journey to natural places to environmental conservation and improve the standard of living of local communities [5]. The principles of ecotourism are in line with the principles of sustainable development, namely maintaining a balance between obtaining economic benefits and maintaining ecological aspects. Various positive benefits of ecotourism can be obtained by professional and responsible management of ecotourism. One form of ecotourism management is a form of community-based management. Form of community-based ecotourism management is a form of management from, by, and for the community. This management principle will foster a sense of belonging in the community over ecotourism which is essentially a legacy of ancestors that will be passed down to the next generation. Researchers focus on community-based ecotourism because community-based ecotourism can directly impact environmental conservation by empowering the potential of the community around the tourist area [6]. Community-based ecotourism creates community pride in local traditions and resources and encourages cultural exchange with visitors. Ecotourism strengthens community relationships and encourages community members to address local problems and find mutually agreeable solutions [7].

One of the ecotourism managed by the community is ecotourism in Cikakak Village, Wangon District, Banyumas Regency. This village has several tourism objects, namely Curug Antap, Religious Tourism Culture of Saka Tunggal Mosque, and feeding apes in the Saka Tunggal mosque area. Ecotourism is managed by a conscious tour group (pokdarwis) Cikakak Village, where each tourism object is managed by each working group (pokja). Ecotourism management in Cikakak Village cannot be separated from the teachings and rituals of the indigenous and cultural Aboge community that inhabits Cikakak Village. Therefore, it is necessary to measure the extent to which the community is involved in managing ecotourism in Cikakak Village. This article seeks to explain the practice of community-based ecotourism management running in Cikakak Village, Wangon Subdistrict, Banyumas Regency and formulate the right strategy in the development of ecotourism in Cikakak village.

\section{Methodology}

This study uses descriptive qualitative methods. The author conducts observations and interviews with ecotourism managers to find out the potential of ecotourism in Cikakak Village and the management practices that have been applied. The author also distributed questionnaires to the residents of Cikakak Village to determine the level of community participation. In the management of ecotourism. In measuring the level of community participation, several indicators developed by Oakley (1991) were used [8]. The indicators are:

- The contribution of the community to the program implementation

- Community involvement in decision making

- Community organizing and control over resources

- Community influence to influence the direction of policy to improve the welfare of the community

In addition, literature studies are also used to know the history and social-cultural conditions of Cikakak Village and enrich understanding of community-based ecotourism management. 
To formulate recommendations for ecotourism management in Cikakak Village, a SWOT analysis is used. SWOT analysis is done by first identifying strengths, weaknesses, opportunities, and threats to ecotourism and then scoring and weighting these components. Based on the score and weight, SWOT analysis is then performed to determine the right strategy based on quadrant as shown in Figure 1: [9].

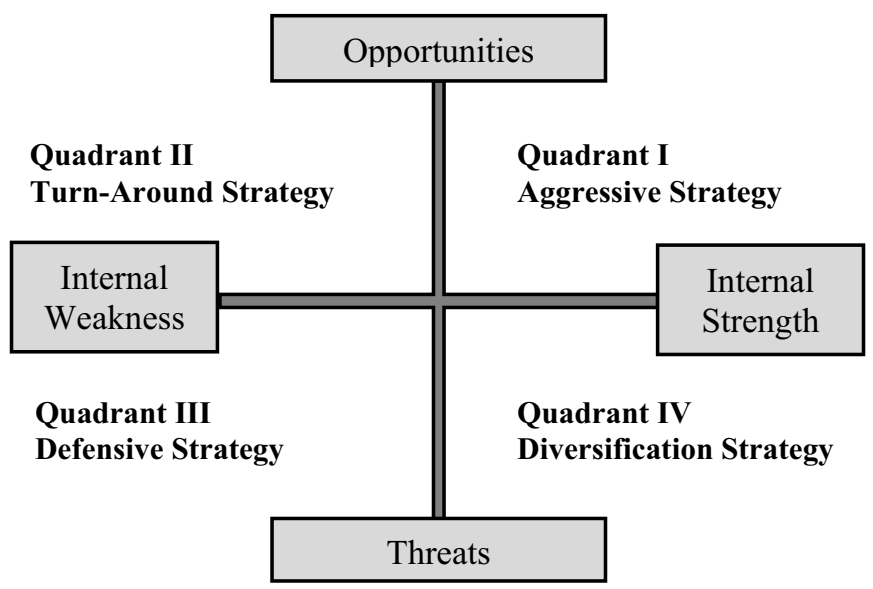

Fig. 1. SWOT Analysis.

\section{Results and Discussion}

\subsection{Ecotourism potential of Cikakak Village}

Cikakak village is categorized as a traditional village because the people still firmly hold the customs inherited by their ancestors [10]. The values inherited by the ancestors in the form of harmony with nature and God made the village potential to become ecotourism. As an ecotourism area, Cikakak Village has three main attractions, namely Curug Antap, Saka Tunggal Mosque, and monkey feeding tours. The uniqueness of each tourism object is as follows.

\subsubsection{Curug Antap}

One of ecotourism in Cikakak village is a waterfall area known as Antap Waterfall. This waterfall is located in the Asahan River in the middle of the pine forest area managed by Perum Perhutani. This tourist attraction is the beautiful natural conditions, with shady pine trees that provide cool air for visitors. In addition, the layout arrangement from the ecotourism entrance to the waterfall location is made beautifully, so some exciting spots are instagrammable. Another attraction of this ecotourism is the existence of "Pasar Jajan" every Sunday. Pasar Jajan sells a variety of traditional Banyumas food that visitors can enjoy. The uniqueness of this Snack Market is that the means of payment used for transactions are in the form of bamboo coins. Visitors must first exchange the money for bamboo coins at the counter available for further payment. The manager of Curug Antap also organizes an entertainment stage every Sunday filled with traditional entertainment to entertain the visitors. 


\subsubsection{Saka Tunggal Mosque}

Saka Tunggal Mosque is a cultural heritage with registration number 11-02/Bas/51/TB/04 located in Cikakak Village. This mosque is the center of worship rituals and the culture of the cikakak village community, which mostly adheres to the Islamic understanding of Aboge (Alip Rebo Wage). Aboge is a traditional Islamic community with the characteristic of a different system in terms of calendar determination. Saka Tunggal Mosque was founded by Kiai Mustholih, a figure spreading Islam in Cikakak Village in 1288 [11]. In terms of architecture, this mosque uses the concept of joglo, which is a form of traditional Javanese house. Joglo shape is characterized by the presence of soko guru in the middle of the building that serves as a column of structures with the primary function of supporting the structure of the building and intercropping, which is the arrangement of several horizontal beams supported by soko guru [12]. The uniqueness of this mosque is the central pillar (soko guru) which only amounts to one and ornaments in the form of wings on the four sides of the central pillar. The central pole is also decorated with ornaments in the form of carvings with striking colors. The structure of Saka Tunggal Mosque can be described as shown in figure 2 as follows [13].

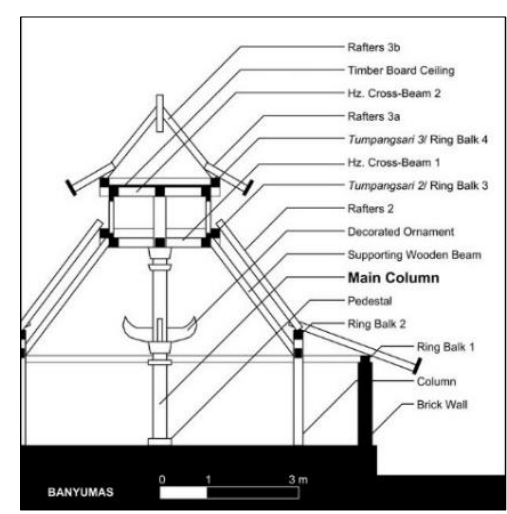

Fig. 2. Section of Saka Tunggal Mosque.

The architectural form of the Saka Tunggal Mosque has a meaning or meaning in it. The number of main pillars of one symbolizes the doctrine of monotheism in Islam. The concept of Saka Tunggal architecture is also found in The Saka Tunggal Kebumen Mosque, Cirebon, and Yogyakarta [13]. Saka Tunggal also means that man must be like an alif (in Arabic letter), straight up, not crooked, honest, and not naughty. Ornaments in the form of four wings mean "papat kiblat limo pancer" or four corners of the wind and one center. The message contained from the symbol is that man as the center is surrounded by four corners of the wind that symbolize the elements of nature, namely fire, wind, water, and earth. Man must be balanced with the elements of nature, do not drown most of the water later, do not play fire if it does not want to burn, do not most wind if you do not want to catch the wind, and do not worship the earth too much if you do not want to fall [14].

\subsubsection{Monkey Feeding Tours}

Aboge community highly upholds the admonitions inherited by Kyai Mustholih, ranging from the issue of worship, coexistence with nature to the passion of life. The Aboge community has a view that animals and plants are inherited from ancestors that must be preserved. Therefore, trees can grow lushly in the Cikakak Village area. Many long-tailed 
monkeys (macaca fascicularis) coexist with the villagers in Cikakak Village, especially around the Saka Tunggal Mosque area. Residents do not dare disturb the apes, let alone kill them, because it can bring disaster [14]. This makes the apes and their habitats still sustainable and can coexist with the population. The existence of these monkeys became an attraction for tourists visiting Cikakak Village Ecotourism.

\subsection{Community Role in Ecotourism Management}

\subsubsection{Management of Antap Waterfall}

Curug Antap is fully managed by the community who are members of the tour-conscious group (pokdarwis). The capital used to organize the location and build facilities around Curug Antap comes from community donations and contributions from pokdarwis members. The revenue from this ecotourism comes from the entrance ticket charged to the visitors, the parking fee charged for visitors who bring vehicles, and the revenue sharing of traders who sell in "Pasar Jajan." The average number of visitors per month is 2.000 to 3.000 visitors, with the most visits every day of the week. Visitors are charged an entrance fee of Rp3.000.00 per person and a parking fee of Rp2.000 per vehicle.

Another source of income ecotourism comes from the revenue sharing of traders who sell in "Pasar Jajan" every Sunday. One of the uniqueness of this snack market is the use of Bamboo Coins as a payment instrument. Visitors can exchange Rp2,500 for one bamboo coin at the available counter and then spend the bamboo coins shopping in "Pasar Jajan."" The price label on each food uses bamboo coins, such as one coin, two coins, and so on. Ecotourism managers do not charge the cost of renting a place from each seller but implement a revenue-sharing system. After Pasar Jajan ends, each trader will exchange bamboo coins that he gets to the ecotourism manager at the exchange rate of one bamboo coin in exchange for Rp2,000. Ecotourism managers take a profit margin of Rp500 from each bamboo coin exchanged by the trader. Ecotourism is proven to provide a significant additional income for people who sell on-site, with an average turnover of Rp1,000,000 per day.

All income earned by Curug Antap is used to improve the facilities and infrastructure of Curug Antap, as well as additional income for the managers. The manager of Curug Antap consists of cikakak village community of approximately fifty people. Every officer who picks to clean the Curug area guards the entrance counter guards the parking lot and earns Rp50,000 per day. This is one of the positive benefits of community-based ecotourism management, namely economic benefits for the community and increased public awareness to maintain the environment. The findings are in line with Indiarti and Munir'sMunir's research (2016) which concluded that the advantage of community-based tourism is the direct impact on environmental conservation by empowering the community around tourist areas [6]. Ecotourism can positively impact the economic aspect if the empowerment of the community around the tourist site is carried out optimally [15].

\subsubsection{Saka Tunggal Mosque Management}

Saka Tunggal Mosque is the center of religious activities in Cikakak Village. This mosque is the center of the traditional and religious rituals of the Aboge Islamic community, which most of the residents of Cikakak Village embrace. Hordes of apes also roam around the mosque so that visitors can feed the monkeys. Before entering the mosque alley, visitors will be charged an entrance ticket of Rp3.000 per person and a parking fee of Rp2.000 per vehicle. The income will be used for community activities on certain days in Cikakak Village. Cikakak villagers earn additional income by selling peanuts for Rp1.000 per pack and 
bananas for Rp2.000 per piece for tourists who want to feed the apes in the Saka Tunggal Mosque area.

Saka Tunggal Mosque is maintained by the people of Cikakak Village, the majority of whom understand Aboge mutually and voluntarily. This mosque is the center of traditional and religious rituals of the Aboge community at certain times, such as jaro jab held every 26th Rajab, muludan to commemorate the birth of the Prophet Muhammad, suran every day of one Muharram, and various other events. Another customary event around the Saka Tunggal Mosque area is Rewandha Bojana, a ceremony to parade the produce that has been formed into gunungan, to be given to monkeys. This ceremony is usually performed in the dry season to help the herd of apes with difficulty foraging [16]. The ceremony symbolizes harmonious life between the community and the monkeys in the Saka Tunggal Mosque area.

The trees in Cikakak Village, especially around the Saka Tunggal Mosque area, the natural habitat of long-tailed macaques, are still beautiful and well maintained. In maintaining the sustainability of nature, Aboge people have a unique principle and are different from society in general. Society, in general, has the principle that "who planted, then he who will harvest." For Aboge people, the quote is considered too optimistic and selfish. Aboge society has the opposite principle, which is "who harvests, then must plant." That view teaches us to be responsible and in harmony with nature [14]. In the form of community commitment, social capital is required to manage ecotourism to prevent the overexploitation of nature [17]. Cikakak Village people have social capital in the form of local wisdom so that ecotourism can be sustainable and managed responsibly.

\subsubsection{Community Participation Rate}

The participation rate of cikakak villagers in ecotourism management is relatively high. The results of measuring the participation rate of the community using questionnaires showed a value of $69,57 \%$ (relatively high). The results show that the community has contributed to the management of ecotourism, involved in decision-making, organizing, and supervision of ecotourism, and determining policy direction in ecotourism development. The highest indicator of community participation in organizing and controlling the community to resources with a value of $77 \%$. The data shows that in managing ecotourism in Cikakak Village, there has been an organizational structure and task sharing tailored to each citizen's capabilities. In addition, there have been community leaders in charge of overseeing the management of ecotourism, and there are complaints channels to report various irregularities. This shows that the concept of community-based ecotourism management has been well implemented in Cikakak Village. Community-based ecotourism requires high engagement from the local community and their active participation. The community will have a sense of belonging and promote resource conservation so that community-based ecotourism can be developed in the best way possible, thus bringing alternative options to the locals and other sectors such as agriculture, resulting in sustainable development. In short, community-based ecotourism will benefit the public [18].

\subsection{SWOT Analysis}

SWOT analysis is focused on identifying internal and external factors that are influential in ecotourism management in Cikakak Village. The results of the analysis will be used to formulate ecotourism management strategies in Cikakak Village.

a) Strength is an advantage owned by Ecotourism in Cikakak Village

1) Ecotourism in Cikakak Village is managed by the surrounding community so that it will be easier in terms of maintenance and supervision of ecotourism areas 
2) Natural conditions in Cikakak Village that are still beautiful and cool that support the development of ecotourism

3) The existence of Saka Tunggal Mosque which has been designated as a Cultural Heritage becomes a special attraction for tourists

4) The existence of The Aboge Islamic community with various customs and local wisdom becomes its attraction for visitors

5) The condition of Antap Waterfall which is still beautiful in the middle of pine trees becomes one of the top tourist attractions in Cikakak Village

6) Ecotourism managers organize "Pasar Jajan" and entertainment stage every Sunday around Curug Antap which is attracted by visitors from various regions

7) Antap Waterfall Manager provides interesting spots for visitors to take pictures

8) Accessibility of Cikakak Village which is easy because it is passed by BanyumasCilacap National Road

9) The fee charged to visitors to enjoy ecotourism in Cikakak Village is relatively cheap

b) Weakness is an internal factor that is considered as a weakness of ecotourism development opportunities in Cikakak Village

1) Lack of promotion and information to the public related to tourist attractions in Cikakak Village

2) Lack of professional personnel in ecotourism management in Cikakak Village

3) Inadequate facilities and infrastructure

4) There are no souvenir shops selling souvenirs or souvenirs typical of Cikakak Village

5) The discharge of water in the Antap Waterfall is small that causes the tourist attraction of Curug Antap in the dry season to decrease

6) Participation of local governments that are still minimal in the development of ecotourism in Cikakak Village

c) Opportunities are external factors that are considered as ecotourism opportunities to develop

1) The tendency of people who now prefer natural and cultural tourism is an opportunity to increase the number of visitors

2) The existence of "Panggung Hiburan" and "Pasar Jajan" rides in Curug Antap can be a means for residents to promote traditional food and local indigenous arts

3) The location of Cikakak Village traversed by National Road so that it is easy to reach by motorcycle, car, or public transportation

4) Banyumas District Government plan to open an industrial area in Randegan Village, which will create an additional potential number of visitors in Cikakak Ecotourism

5) With the Ecotourism of Cikakak Village, is expected to provide direct benefits for the people of Cikakak Village

d) Threats are external factors that are considered as something that can threaten the sustainability of ecotourism

1) Conflicts of interest with other parties due to the absence of written cooperation agreements related to the utilization of forest areas

2) Disruption of the natural habitat of long-tailed monkeys in Cikakak Village due to tourism activities

3) The influx of tourists with outside culture is feared to affect the local wisdom of villagers who have lived balanced with nature

4) Socioeconomic condition of cikakak villagers who have not been so developed

5) Tourists who visit Cikakak Village have the potential to pollute the environment by littering, scribbling, and so on 


\subsection{Ecotourism Development Recommendations}

Swot analysis shows that ecotourism management in Cikakak Village is in Quadrant I as shown in figure 3 as follows.

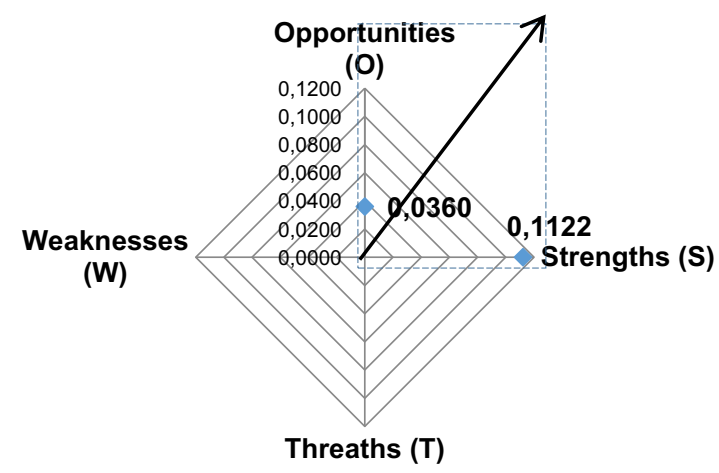

Fig. 3. Result of SWOT Analysis.

Based on Figure 3, it appears that The Cikakak village ecotourism position is in Quadrant I. Quadrant I is the most profitable position, so with the power, it is possible to take advantage of the opportunities available. In other words, management has many strategic options that can be used for business development [19]. The ecotourism Manager in Cikakak Village must maintain the ecotourism conditions because quadrant I am the most profitable position. The combination of potential solid opportunities and comparative strengths of the organization gives real opportunities. It is the central space for articulating an efficient strategy [20]. Therefore, Ecotourism Managers in Cikakak Village can implement the SO Strategy (Aggressive strategy) by maximizing their power to exploit existing opportunities. Some strategies that can be applied in ecotourism management in Cikakak Village are:

1) Expanding the tourist area of Curug Antap and adding photo spots for visitors.

2) Add the variety of entertainment featured in "Panggung Hiburan."

3) Expanding the land "Pasar Jajan" and inviting more residents of Cikakak Village and surrounding villages to sell in the market.

4) Put up an attractive banner on the side of the national road so that road users know the attraction of ecotourism in Cikakak Village.

\section{Conclusions}

Ecotourism Cikakak Village has a tourist attraction in Curug Antap and Cultural Tourism in The Saka Tunggal Mosque. The community manages Curug Antap through conscious tourism groups (pokdarwis) Cikakak Village. At the same time, the management of Saka Tunggal Mosque is carried out by the Aboge community, which makes Saka Tunggal Mosque the center of traditional and religious rituals. One of the social capital owned by the cikakak village community in managing ecotourism is local wisdom that teaches to live in harmony with nature. Community-based ecotourism management is also proven to provide direct benefits in the form of the creation of culinary business opportunities around the site and additional income from ecotourism management. The level of community participation in ecotourism management in Cikakak Village is relatively high to become capital in the development of ecotourism. Cikakak Village Ecotourism Manager can implement SO strategy (aggressive strategy) in ecotourism development by maximizing the power to take 
advantage of current opportunities. Some strategies that can be applied in ecotourism management in Cikakak Village are:

1) Expanding the tourist area of Curug Antap and adding photo spots for visitors.

2) Add the variety of entertainment featured in "Panggung Hiburan."

3) Expanding the land "Pasar Jajan" and inviting more residents of Cikakak Village and surrounding villages to sell in the market.

4) Put up an attractive banner on the side of the national road, so that road users know the attraction of ecotourism in Cikakak Village.

Some alternative strategies produced in this study are expected to be applied in the management of ecotourism in Cikakak Village to provide economic benefits for the community, conservation benefits for the environment, and the preservation of the native culture of Cikakak Village.

\section{References}

1. C. Kusmana, A. Hikmat, Keanekaragaman hayati flora di Indonesia, J Pengelolaan SDA dan Lingkung, 5, 187-98 (2015)

2. Badan Pusat Statistik, Statistik lingkungan hidup indonesia 2020, Badan Pus Stat. (2020)

3. OECD, OECD Tourism Trends and Policies 2020, (Paris, France 2020)

4. I. N. S. Arida, Ekowisata: Pengembangan, partisipasi lokal dan tantangan ekowisata, (CAKRA Press Denpasar 2017)

5. J. A. Seba, Ecotourism and sustainable tourism new perspectives and studies, Tourism and the Economy, (Apple Academic Press Inc. Oakville 2012)

6. W. Indiarti, A. Munir, The Implementation of community-based ecotourism concept in osing tourism village development strategy of Banyuwangi Regency, Indonesia, in proceedings of the Asia Tourism Forum 2016-The 12th Biennial Conference of Hospitality and Tourism Industry in Asia (ATF-16), 68-73 (2016)

7. P. Treephan, P. Visuthismajarn, S. A. Isaramalai, A model of participatory community-based ecotourism and mangrove forest conservation in Ban Hua Thang, Thailand, African J Hosp Tour Leis, 8(5), 1-8 (2019)

8. P. Oakley, Projects with people: the practice of participation in rural development. Projects with people: the practice of participation in rural development, (ILO Geneva, 1991)

9. F. Rangkuti, Analisis SWOT: Teknik membedah kasus bisnis cara perhitungan bobot, rating, dan OCAI, (Gramedia Pustaka Utama Jakarta 1997)

10. Y. Suprapto, D. M. M. Nur, D. Retno, M. Luqman, Internalisasi nilai-nilai islam komunitas aboge kepada anak usia sekolah dasar di Desa Cikakak Kecamatan Wangon Kabupaten Banyumas, IJTIMAIYA J Soc Sci Teach., (2020)

11. A. Rachmadhani, Role of Wali, Ancient mosque and sacred tomb in Islam Spreading Dynamics in Cikakak, IBDA`J Kaji Islam dan Budaya, (2016)

12. C. Moniaga, A. Gunawan, Rumah joglo sebagai identitas visual konsep bangunan kuliner kontemporer, J Desain Komun Vis dan Media Baru, 1, (2019)

13. A. S. Wibowo, S. Sasano, Historical assessment of the Saka Tunggal Mosque in Banyumas: Study on the single column mosque on Java Island, Indonesia, J Asian Archit Build Eng., (2016)

14. M. L. Amin, Eko-Sufisme islam aboge Masjid Saka Tunggal Cikakak Banyumas, J Penelit., (2017)

15. A. Sangpikul, Ecotourism impacts on the economy, society and environment of Thailand, J Rev Glob Econ., (2017)

16. I. M. Sholikhah, D. Adiarti, A. N. Kholifah, Local wisdom reflected in the symbols 
in Masjid Saka Tunggal Banyumas, IBDA`J Kaji Islam dan Budaya, (2017)

17. S. Jones, Community-based ecotourism: The significance of social capital, Ann Tour Res, 32(2), 303-24 (2005)

18. Z. B. Beza, Challenges and prospects of community based ecotourism development in Lake Zengena and its environs, North West Ethiopia, African J Hosp Tour Leis, 6(3), (2017)

19. P. Wardoyo, Alat analisis manajemen, Edisi 1, (Semarang University Press 2011)

20. C. Vlados, On a correlative and evolutionary SWOT analysis, J Strateg Manag., 12(3), 347-63 (2019) 